\title{
Assessment of hydrocarbon generation potential and thermal maturity of the offshore Mannar Basin, Sri Lanka
}

\author{
Amila Sandaruwan Ratnayake ${ }^{1,2} \cdot$ Chaminda Wimal Kularathne $^{3} \cdot$ Yoshikazu Sampei $^{1}$
}

Received: 17 July 2017 / Accepted: 26 November 2017 / Published online: 9 December 2017

(c) The Author(s) 2017. This article is an open access publication

\begin{abstract}
The Mannar Basin is an under-explored offshore sedimentary basin in terms of petroleum geology. The Cretaceous to Paleogene cutting samples were collected in three offshore exploration wells (i.e. the Dorado North, Dorado and Barracuda) in the Mannar Basin. In this study, kerogen type, quantity and thermal maturity of sedimentary organic matter were ascertained using Rock-Eval pyrolysis and vitrinite reflectance analyses. In addition, 1-D basin modelling was used to analyse the timing of hydrocarbon generation in the Mannar Basin. Total organic carbon (TOC) contents and total hydrocarbon potential are higher in the Cretaceous calcareous mudstones than in the Paleogene calcareous silty/sandy mudstones. TOC contents show a negative correlation with oxygen index. Hydrogen index and oxygen index values range from 77 to $785 \mathrm{mg} \mathrm{HC} / \mathrm{g}$ TOC and from 25 to $165 \mathrm{mg} \mathrm{HC/g}$ TOC, respectively. Organic matters were identified as mixed Type II-III and Type III kerogen. Maturity expressed in term of Tmax and vitrinite reflectance range from 332 to $456{ }^{\circ} \mathrm{C}$ and from 0.26 to $1.49 \%$, respectively. It indicates both immature and mature sediments. In general, maturity values are relatively high in the Late Cretaceous sediments (Tmax, from 332 to $456{ }^{\circ} \mathrm{C}$, average $=423{ }^{\circ} \mathrm{C} \pm 25$ ) compared to the Paleogene sediments (Tmax, from 388 to $431{ }^{\circ} \mathrm{C}$, average $419^{\circ} \mathrm{C} \pm 10$ ). Geochemical proxies show that oil and gas prone (Type II-III) and gas prone (Type III) kerogen-rich Late Cretaceous sediments of the Dorado and Barracuda wells have principally achieved maturity levels for oil window. Therefore, it suggests incomplete thermal conversion for the wet gas generation in the northeast part of the Mannar Basin. In the 1-D basin modelling, the maximum hydrocarbon generation was observed during the Neogene Period in the Late Cretaceous sediments of the deeper Barracuda well.
\end{abstract}

Keywords Rock-Eval pyrolysis $\cdot$ Vitrinite reflectance $\cdot$ Kerogen type $\cdot 1$-D kinetic modelling $\cdot$ Petroleum geochemistry

\section{Introduction}

The Mannar Basin is one of the largest geological provinces for the hydrocarbon exploration in Sri Lanka (Fig. 1). The tectonic settings of this basin have considerably influenced the distribution of basic sedimentary patterns (Ratnayake et al. 2014). In addition, previous investigations suggested

Amila Sandaruwan Ratnayake

amilageopera@gmail.com

1 Department of Geoscience, Faculty of Science and Engineering, Shimane University, Nishikawatsu-cho 1060, Matsue 690-8504, Japan

2 Present Address: Faculty of Science and Technology, Uva Wellassa University, Passara Road, Badulla 90000, Sri Lanka

3 Petroleum Resources Development Secretariat (PRDS), Level 06, Ceylinco House 69, Janadhipathi Mawatha, Colombo 01, Sri Lanka that the Mannar Basin is a prolific producer of both gas and oil in the currently explored deepwater area based on numerical estimation in the framework of the basin modelling and considering actual lithological composition (Ratnayake and Sampei 2015b). Thus, it makes a potential target area for future oil and gas exploration in Sri Lanka (Ratnayake et al. 2017a). These previous investigations were carried out based on limited geochemical data regarding the hydrocarbon generation potential and thermal maturity of the offshore Mannar Basin.

Rock-Eval pyrolysis is the most widely applied standard method in petroleum industry to characterise hydrocarbon generation potential (quantity), types of kerogen, types of primary hydrocarbons (oil and gas) and thermal maturity of sedimentary organic matter (e.g. Espitalié et al. 1977; Katz 1983; Delvaux et al. 1990; Langford and Blanc-Valleron 1990; Vandenbroucke and Largeau 2007; Adegoke et al. 2015; Jiang et al. 2015). In addition, vitrinite reflectance is 
Fig. 1 Basic geological setting of the Mannar Basin and locations of exploration wells

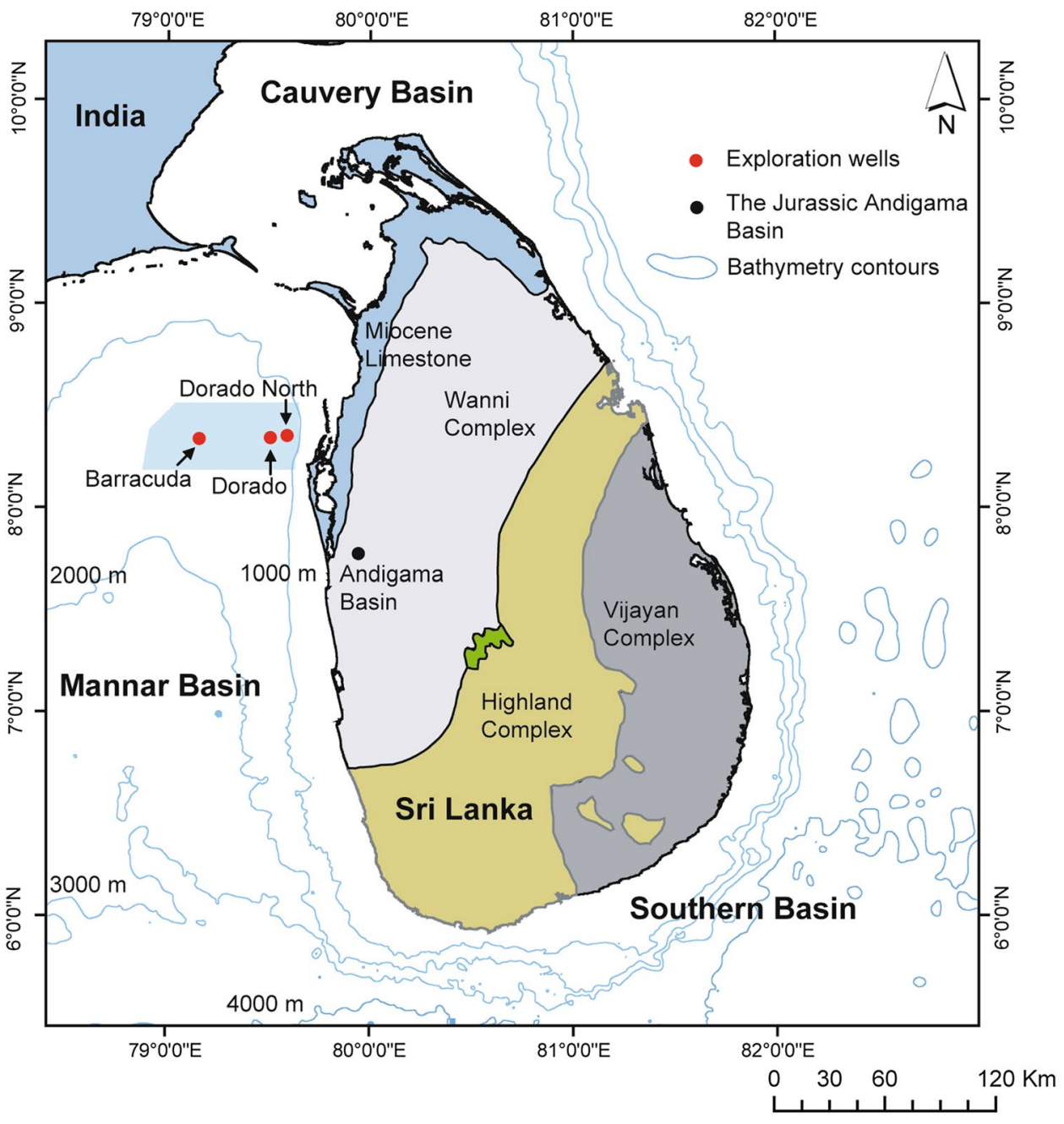

an optical thermal maturity indicator of sedimentary organic matter since Silurian (Ritter 1984; Sweeney and Burnham 1990; Uysal et al. 2000; Mani et al. 2015). Petroleum geochemists generally deal with these analytical results together with standard reference diagrams and numerical modelling for identifying potential source rock beds (e.g. Welte and Yukler 1981; Tissot et al. 1987; Pepper and Corvi 1995; Pepper and Dodd 1995; Abbassi et al. 2014; Mashhadi et al. 2015). The current study is based on the detailed interpretation of qualitative and quantitative aspects of hydrocarbon generation potential and thermal transformation of organic matter using Rock-Eval pyrolysis and vitrinite reflectance (Ro\%) data. In addition, compositional kinetics models were considered to determine the evolution of thermal maturity and timing of hydrocarbon generation. This study thus provides basic information for the hydrocarbon exploration works in Sri Lanka.

\section{Study area}

The Mannar Basin is a north-south trending offshore sedimentary basin that is located between southeast of India and southwest to northeast of Sri Lanka (Fig. 1). The basin covers an area of $45,000 \mathrm{~km}^{2}$ in Sri Lankan jurisdiction. The basement of the Mannar Basin consists of Precambrian high-grade metamorphic rocks (Cooray 1984). Tectonostratigraphic evolution of the Mannar Basin can be mainly identified as three phases of possible pre-rift, rift and postrift. Rift phase can be mainly subdivided into early and late syn-rift phases (the Middle Jurassic to Early Cretaceous). Rift transition (or post-rift) is considered with thermal sag phase during the Late Cretaceous and an inversion episode during the Oligocene and Miocene Epochs (Shaw 2002; Kularathna et al. 2015). 
The early rifting of the Mannar Basin was related to the late disaggregation of eastern and western Gondwana during the Middle Jurassic Period (Molnar and Tapponnier 1975). This tectonic breakup was associated with the opening of the Indian Ocean (McKenzie and Sclater 1971; Norton and Sclater 1979). The consecutive extensional (rifting) activities resulted in the deposition of terrestrial and marine sedimentary organic matter in the offshore Mannar Basin over nearly 167 million years from the Jurassic to recent in age (Fig. 2). The horsts and tilted fault blocks and compression induced traps were mainly developed during the rifting process and provided encouraging exploration opportunities in this basin (Shaw 2002).

The Mannar Basin continuously subsided since its rifting and resulted in the deposition of a thick sedimentary succession (Fig. 2). The sediment thickness around the present day depocenter of the Mannar Basin exceeds over $6 \mathrm{~km}$ (Ratnayake et al. 2017a). Several studies have demonstrated the wide range of dark colour mudstones from the Jurassic to Cretaceous Periods in neighbouring offshore and onshore sedimentary basins in India, and the Jurassic onshore sedimentary basins in Sri Lanka (e.g. Chandra et al. 1991; Ratnayake and Sampei 2015a). These rocks are possibly related to potential source rock beds in the Mannar Basin. The fragmentation of Madagascar, Laxmi Ridge/Seychelles and Seychelles from the Indian plate was associated with extensive rifting activities (Storey et al. 1995; Chatterjee et al. 2013). In addition, such sequential separations were followed by intrusive and extrusive igneous provenance in the Mannar Basin (Fig. 2). In contrast, the mid to late Cenozoic carbonates-rich sediments in the Mannar Basin can probably indicate climatic transition from arid to tropical conditions (Ratnayake et al. 2014; Ratnayake 2016).

\section{Materials and methods}

\section{Materials}

The cutting samples were collected from three exploration wells of the Dorado North, Dorado and Barracuda in the Mannar Basin. All the exploration wells are located on the northeast margin of the basin (Fig. 1). The offshore commercial drilling program was conducted from 201108-12 to 2011-11-20 using the scientific riser-equipped deepwater drillship Chikyu. The present water depths of the Dorado North, Dorado and Barracuda wells are 1346.4, 1383 and $1509 \mathrm{~m}$, respectively. The sampling depths of the Dorado North, Dorado and Barracuda wells are 2200-3622, 2150-3288 and 2139-4741 m, respectively (Fig. 2). The Dorado and Barracuda wells were plugged as gas discovered wells, and the Dorado North was plugged as a dry well. The Late Cretaceous sediments depths of the Dorado North, Dorado and Barracuda exploration wells are 3010-3622, 2850-3288 and 3440-4741 m, respectively (Fig. 2). The Paleogene sediments depths of the Dorado North, Dorado and Barracuda exploration wells are 2200-3010, 2150-2850 and 2340-3440 m, respectively (Fig. 2).

\section{Geochemical analysis}

In this study, the extraction was performed to remove oilbased mud contaminants using the dichloromethane: methanol 9:1 v/v solution. All geochemical analysis was carried out on these solvent extracted samples. According to the Ichron limited technical report (2012), Rock-Eval pyrolysis was performed for 71 samples on ca. $100 \mathrm{mg}$ of powdered samples. Samples were heated from 300 to $550{ }^{\circ} \mathrm{C}$ in a helium atmosphere, according to standard procedures. This analysis provides the following measured parameters including Tmax (the temperature of maximum pyrolysis peak at $S_{2}$, ${ }^{\circ} \mathrm{C}$ ), $S_{1}$ (the amount of naturally generated hydrocarbons or the free hydrocarbons, $\mathrm{mg} \mathrm{HC/g}$ rock), and $S_{2}$ (the amount of hydrocarbons produced during pyrolysis, $\mathrm{mg} \mathrm{HC/g}$ rock). The measured parameters were used to calculate standard geochemical proxies such as hydrogen index (HI), oxygen index (OI) and production index (PI) based on the literature (e.g. Espitalié et al. 1977; Tissot et al. 1980, 1987; Peters and Cassa 1994).

Vitrinite reflectance (Ro\%) was measured on selected 45 manually crushed samples at EGS-Ploration laboratory based on procedure mentioned in the Ichron limited technical report (2012). Ro determination was performed under oil immersion $\left(n_{\mathrm{e}} 1.517\right.$, at $\left.23{ }^{\circ} \mathrm{C}\right)$ of incident white light $(546 \mathrm{~nm})$ with a Zeiss Standard Universal research microscope-photometer system (MPM01 K). Samples were calibrated against certified standards of $0.413,0.506,0.917$, $1.025,1.817$ and $3.256 \%$.

\section{Basin modelling}

Kinetic models of the Mannar Basin were generated using actual lithostratigraphic and geochemical data together with burial model and geothermal properties (the standard rifting heat flow) using the software package of Basin Mod 1-D at Shimane University, Japan. In detail, standard burial history model was initially prepared using age and present thickness of the each sedimentary facies. Actual lithologies were determined by mixing the percentages of the default compositions.

Similarly, kerogen types (organofacies) were defined for each sedimentary facies considering the mixing of standard

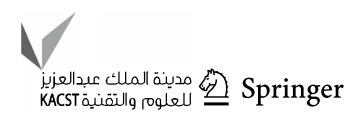




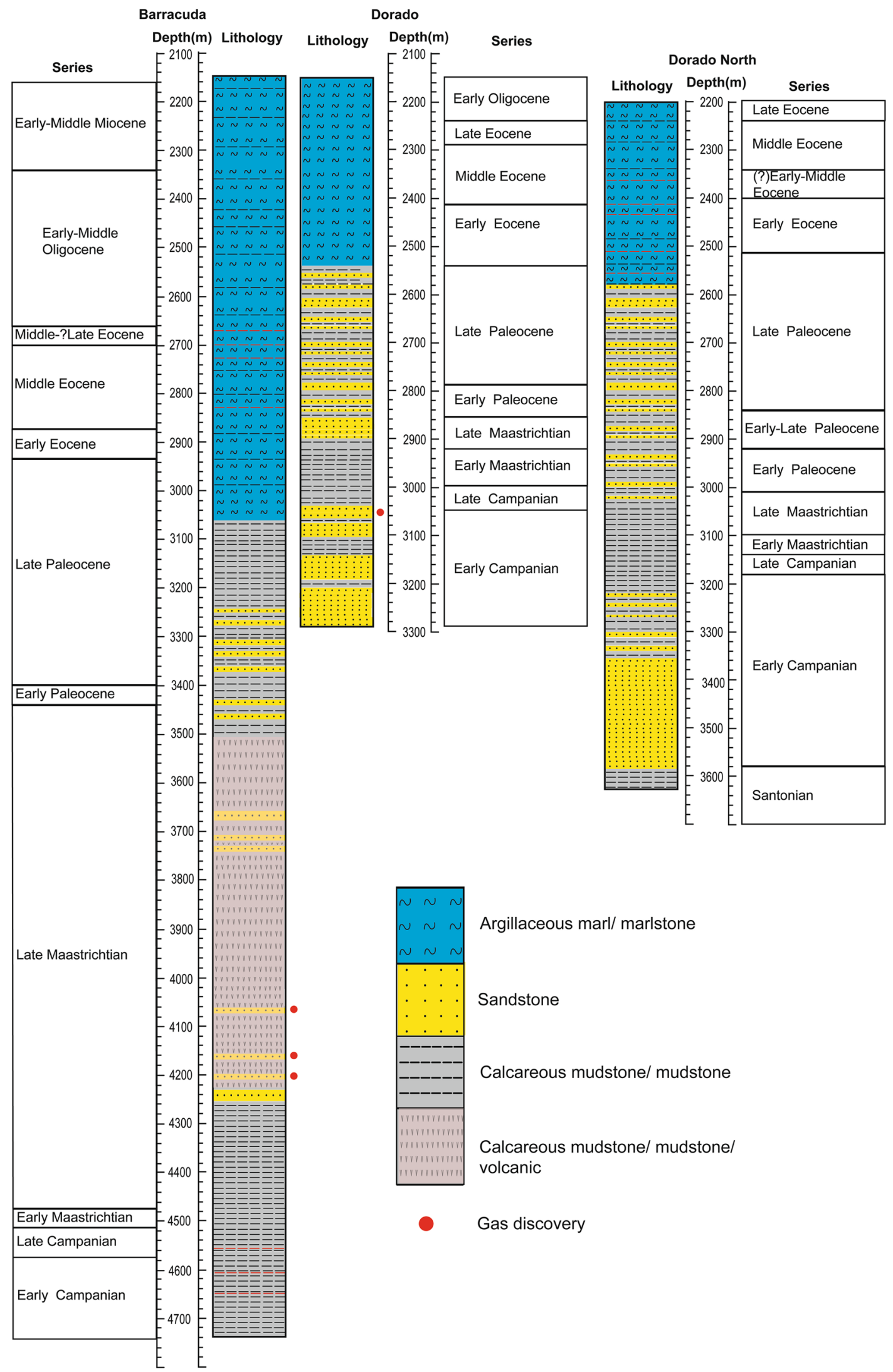

Fig. 2 Lithostratigraphic sections of the Dorado North, Dorado, and Barracuda exploration wells in the Mannar Basin (modified after Ratnayake et al. 2014; Kularathna et al. 2015) 
Type I, Type II and Type III kerogen based on Rock-Eval pyrolysis data. Moreover, geochemical data such as total organic carbon, hydrogen index, oxygen index, Tmax and vitrinite reflectance were manually entered for the each sedimentary facies. Therefore, geochemical data can be used to edit kinetic window with reference to maturity parameters. For example, transformation ratio (i.e. the ratio of hydrocarbons generated to the genetic potential) depends on kerogen types and maturity. In contrast, kinetic model qualitatively predicts multiple components of oil and gas generation from different kerogen types. Basin Mod 1-D software consists of default kinetic parameters for the standard Type I, Type II and Type III kerogen. The kinetic parameters for the mixed kerogen types can be derived from the default values of Type I, Type II and Type III kerogen. In addition, these kinetic parameters include reaction fraction (percentage of kerogen with specific activation energy), activation energy (energy required for bond rupture) and Arrhenius constant/frequency factor (frequency with a certain reaction takes place).

According to the literature, standard rifting heat flow was used as the most applicable method for estimating paleothermal history of the Mannar Basin (e.g. Ratnayake and Sampei 2015b). Therefore, these simplified kinetic models were used to evaluate thermal history and timing of hydrocarbon generation in the Mannar Basin.

\section{Results and discussion}

\section{Organic richness and kerogen type}

Total organic carbon (TOC) is a fundamental proxy to identify organic matter richness in sediments and sedimentary rocks (e.g. Tissot and Welte 1978; Jiang et al. 2015; Mani et al. 2015; Ratnayake et al. 2017b). TOC values range from 0.55 to $2.10 \mathrm{wt} \%$ with an average of $1.16 \pm 0.39 \mathrm{wt} \%$ (Table 1). Organic richness is higher in the Cretaceous calcareous mudstones (averages of $1.39 \mathrm{wt} \%$ in Dorado and $1.37 \mathrm{wt} \%$ in Barracuda) than in the Paleogene calcareous silty/sandy mudstones (averages of $1.19 \mathrm{wt} \%$ in Dorado and $0.87 \mathrm{wt} \%$ in Barracuda; Table 1). Similarly, total hydrocarbon potential (amount of naturally generated hydrocarbons or the free hydrocarbons of $S_{1}$ and amount of hydrocarbons produced during pyrolysis of $S_{2}$ ) is also higher in the Cretaceous sediments (averages of $3.97 \mathrm{mg} \mathrm{HC/g}$ rock in Dorado and $5.23 \mathrm{mg} \mathrm{HC} / \mathrm{g}$ rock in Barracuda) than in the Paleogene sediments (averages of $3.88 \mathrm{mg} \mathrm{HC/g}$ rock in Dorado and $2.24 \mathrm{mg} \mathrm{HC} / \mathrm{g}$ rock in Barracuda; Table 1 and Fig. 3). Therefore, TOC has a good correlation with total hydrocarbon potential in analysed sediments (Fig. 4). In addition, the relationship between TOC and the amount of hydrocarbon yield from cracked kerogen $\left(S_{2}, \mathrm{mg} \mathrm{HC} / \mathrm{g}\right.$ rock) can be used to estimate the generation potential of source rocks (Peters 1986; Langford and Blanc-Valleron 1990; Peters and Cassa 1994; Hakimi et al. 2010). $S_{2}$ values vary between 0.66 and $9.01 \mathrm{mg} \mathrm{HC} / \mathrm{g}$ rock with an average of $3.09 \pm 1.86 \mathrm{mg} \mathrm{HC} / \mathrm{g}$ rock (Table 1). In general, a significant amount of the analysed samples recorded more than $1.0 \mathrm{wt} \%$ of TOC, and more than $4 \mathrm{mg} \mathrm{HC} / \mathrm{g}$ rock of $S_{2}$ yield in Rock-Eval pyrolysis. Consequently, these results indicate fair to good source rock generative potential in the representative stratigraphic units (Fig. 5).

The modified Van Krevelen diagram of hydrogen index (HI) versus oxygen index (OI) is regarded as one of the reliable ways to recognise the dominant kerogen type of organic matter (Tissot and Welte 1978; Tissot et al. 1980, 1987). HI values vary between 77 and $785 \mathrm{mg} \mathrm{HC} / \mathrm{g}$ TOC with an average of $263 \pm 139 \mathrm{mg} \mathrm{HC} / \mathrm{g}$ TOC (Table 1). OI values range between 25 and $165 \mathrm{mg} \mathrm{HC/g}$ TOC with an average of $71 \pm 32 \mathrm{mg} \mathrm{HC} / \mathrm{g}$ TOC (Table 1). In general, it suggests large variations in an origin of organic matter compositions and oxic/anoxic depositional conditions. However, most of the studied samples plotted in the zone of mixed Types II-III (oil and gas prone) and Type III (gas prone) kerogen in the potential source rocks (Fig. 6). Therefore, gas generation can be mainly expected under the conditions of adequate burial and heating. On the other hand, the mixed Type II-III kerogen can also suggest deposition of either terrigenous and marine organic matter or poor preservation of Type I and II kerogen under strongly oxidised conditions.

TOC has a negative correlation with OI values (Fig. 7). However, original geochemical fingerprints can still remain under the influence of low OI values ( $<200 \mathrm{mg} \mathrm{HC/g}$ TOC) (Arab et al. 2015). Therefore, the majority of samples consist of mixed Type II-III kerogen rather than biodegraded or oxidised Type I or Type II kerogen. In contrast, HI values were apparently increased in few samples such as in Dorado North 3155, 3190 and $3295 \mathrm{~m}$ (Table 1 and Fig. 6). This anomaly can probably indicate contamination with remained drilling mud/oil and/or migrated hydrocarbon in reservoir rocks. In addition, it is followed by higher migration index $\left(S_{1} /\right.$ TOC ratio, greater than 1.5; Table 1). Previous studies suggested that heavy hydrocarbons such as resins and asphaltenes can be realised at the $S_{2}$ peak with the same temperature range as for kerogen pyrolysis (Delvaux et al. 1990).

The ratio of the amount of hydrocarbon produced during pyrolysis $\left(S_{2}\right)$ and the amount of carbon dioxide produced during pyrolysis $\left(S_{3}\right)$ versus organic richness are directly related to type and quantity of potential hydrocarbon. Therefore, Fig. 8 clearly indicates deposition of gas-prone to oilprone mixed organic matter in fair to good source rocks.

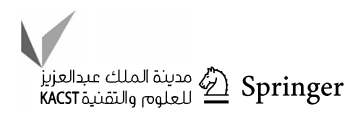


Table 1 Rock-Eval pyrolysis and vitrinite reflectance (Ro) data from the Dorado North, Dorado, and Barracuda exploration wells in the Mannar Basin

\begin{tabular}{|c|c|c|c|c|c|c|c|c|c|c|c|c|c|c|c|}
\hline \multirow[t]{2}{*}{ Exploration well } & \multirow[t]{2}{*}{ Depth (m) } & \multirow[t]{2}{*}{ Reference no. } & \multirow[t]{2}{*}{ TOC (\%) } & \multicolumn{9}{|c|}{ Rock-Eval pyrolysis } & \multicolumn{3}{|c|}{ Vitrinite reflectance } \\
\hline & & & & $S_{1}$ & $S_{2}$ & $S_{1}+S_{2}$ & $S_{3}$ & HI & OI & MI & PI & Tmax & Ro (\%) & SD & Counts \\
\hline Dorado North & 3155 & $2643-2$ & 0.74 & 1.66 & 4.09 & 5.75 & 1.22 & 553 & 165 & 2.24 & 0.29 & 377 & & & \\
\hline Dorado North & 3165 & $2643-3$ & 0.67 & 0.10 & 0.98 & 1.08 & 0.34 & 146 & 51 & 0.15 & 0.09 & 419 & & & \\
\hline Dorado North & 3180 & $2643-5$ & 0.78 & 0.40 & 3.67 & 4.07 & 0.60 & 471 & 77 & 0.51 & 0.10 & 412 & & & \\
\hline Dorado North & 3190 & $2643-6$ & 1.09 & 1.01 & 6.99 & 8.00 & 0.78 & 641 & 72 & 0.93 & 0.13 & 398 & 0.82 & 0.05 & 12 \\
\hline Dorado North & 3295 & $2643-15$ & 0.55 & 1.20 & 4.32 & 5.52 & 0.90 & 785 & 164 & 2.18 & 0.22 & 399 & & & \\
\hline Dorado North & 3520 & $2643-21$ & 0.88 & 0.21 & 1.98 & 2.19 & 0.39 & 225 & 44 & 0.24 & 0.09 & 433 & & & \\
\hline Dorado North & 3535 & $2643-22$ & 0.90 & 0.60 & 2.67 & 3.27 & 0.43 & 297 & 48 & 0.67 & 0.18 & 419 & 0.58 & 0.06 & 18 \\
\hline Dorado North & 3550 & $2643-23$ & 1.31 & 1.01 & 5.54 & 6.55 & 0.79 & 423 & 60 & 0.77 & 0.15 & 423 & 0.61 & 0.03 & 20 \\
\hline Dorado North & 3565 & $2643-24$ & 1.09 & 0.45 & 3.09 & 3.54 & 0.34 & 283 & 31 & 0.41 & 0.13 & 425 & 0.73 & 0.05 & 20 \\
\hline Dorado North & 3580 & $2643-25$ & 0.78 & 0.09 & 0.91 & 1.00 & 0.60 & 117 & 77 & 0.12 & 0.09 & 426 & & & \\
\hline Dorado North & 3590 & $2643-26$ & 0.95 & 0.23 & 3.66 & 3.89 & 0.81 & 385 & 85 & 0.24 & 0.06 & 427 & 0.83 & 0.04 & 11 \\
\hline Dorado North & 3605 & $2643-27$ & 0.91 & 0.10 & 3.01 & 3.11 & 0.71 & 331 & 78 & 0.11 & 0.03 & 424 & 0.77 & 0.05 & 11 \\
\hline Dorado North & 3615 & $2643-28$ & 1.11 & 0.61 & 5.45 & 6.06 & 0.88 & 491 & 79 & 0.55 & 0.10 & 427 & 0.90 & 0.07 & 10 \\
\hline Average (Cretaceous) & & & 0.90 & 0.59 & 3.57 & 4.16 & 0.68 & 396 & 79 & 0.70 & 0.13 & 416 & 0.75 & 0.05 & 15 \\
\hline Dorado & 2210 & $2579-5$ & 1.13 & 0.78 & 3.59 & 4.37 & 1.07 & 318 & 95 & 0.69 & 0.18 & 419 & 0.26 & 0.01 & 5 \\
\hline Dorado & 2270 & $2579-9$ & 0.99 & 0.55 & 2.31 & 2.86 & 0.69 & 233 & 70 & 0.56 & 0.19 & 415 & 0.31 & 0.02 & 6 \\
\hline Dorado & 2340 & $2579-13$ & 1.10 & 0.49 & 3.23 & 3.72 & 0.77 & 294 & 70 & 0.45 & 0.13 & 412 & 0.38 & 0.04 & 6 \\
\hline Dorado & 2510 & $2579-16$ & 1.16 & 0.61 & 3.67 & 4.28 & 0.67 & 316 & 58 & 0.53 & 0.14 & 415 & 0.41 & 0.02 & 7 \\
\hline Dorado & 2645 & $2580-10$ & 1.36 & 0.87 & 2.78 & 3.65 & 0.59 & 204 & 43 & 0.64 & 0.24 & 426 & 0.42 & 0.04 & 9 \\
\hline Dorado & 2715 & $2580-13$ & 1.34 & 0.77 & 3.19 & 3.96 & 0.65 & 238 & 49 & 0.57 & 0.19 & 426 & 0.47 & 0.03 & 8 \\
\hline Dorado & 2785 & $2580-17$ & 1.28 & 2.45 & 1.87 & 4.32 & 0.45 & 146 & 35 & 1.91 & 0.57 & 422 & 0.52 & 0.04 & 7 \\
\hline Dorado & 2890 & $2580-20$ & 1.25 & 2.33 & 2.84 & 5.17 & 0.88 & 227 & 70 & 1.86 & 0.45 & 420 & 0.55 & 0.05 & 7 \\
\hline Dorado & 2905 & $2580-21$ & 1.20 & 1.11 & 3.01 & 4.12 & 0.56 & 251 & 47 & 0.93 & 0.27 & 422 & 0.69 & 0.01 & 2 \\
\hline Dorado & 2920 & $2580-22$ & 1.31 & 1.44 & 4.02 & 5.46 & 0.88 & 307 & 67 & 1.10 & 0.26 & 421 & 0.56 & 0.05 & 5 \\
\hline Dorado & 2935 & $2580-23$ & 1.19 & 0.98 & 2.34 & 3.32 & 1.89 & 197 & 159 & 0.82 & 0.30 & 419 & 0.64 & 0.04 & 4 \\
\hline Dorado & 2950 & $2580-24$ & 1.56 & 1.77 & 2.89 & 4.66 & 0.77 & 185 & 49 & 1.13 & 0.38 & 399 & 0.68 & 0.03 & 4 \\
\hline Dorado & 2965 & $2580-25$ & 1.49 & 2.27 & 2.62 & 4.89 & 0.67 & 176 & 45 & 1.52 & 0.46 & 336 & 0.69 & 0.03 & 6 \\
\hline Dorado & 2980 & $2580-26$ & 1.52 & 3.53 & 2.79 & 6.32 & 0.85 & 184 & 56 & 2.32 & 0.56 & 332 & 0.73 & 0.07 & 7 \\
\hline Dorado & 2995 & $2580-27$ & 1.67 & 1.98 & 4.01 & 5.99 & 0.79 & 240 & 47 & 1.19 & 0.33 & 412 & 0.68 & 0.05 & 2 \\
\hline Dorado & 3010 & $2580-28$ & 1.32 & 0.34 & 1.89 & 2.23 & 0.67 & 143 & 51 & 0.26 & 0.15 & 442 & 0.83 & 0.03 & 3 \\
\hline Dorado & 3025 & $2580-29$ & 1.19 & 0.29 & 2.11 & 2.40 & 0.77 & 177 & 65 & 0.24 & 0.12 & 440 & 0.69 & 0.06 & 4 \\
\hline Dorado & 3035 & $2580-30$ & 1.67 & 0.45 & 3.01 & 3.46 & 0.80 & 180 & 48 & 0.27 & 0.13 & 439 & 0.93 & 0.07 & 5 \\
\hline Dorado & 3090 & $2580-31$ & 1.31 & 0.61 & 2.09 & 2.70 & 0.78 & 160 & 60 & 0.47 & 0.23 & 441 & 0.94 & 0.07 & 7 \\
\hline Dorado & 3095 & $2580-32$ & 1.18 & 0.19 & 1.34 & 1.53 & 0.61 & 114 & 52 & 0.16 & 0.12 & 446 & & & \\
\hline Dorado & 3100 & $2580-33$ & 0.99 & 0.32 & 0.98 & 1.30 & 0.50 & 99 & 51 & 0.32 & 0.25 & 444 & & & \\
\hline Dorado & 3115 & $2580-34$ & 1.77 & 0.22 & 2.98 & 3.20 & 0.71 & 168 & 40 & 0.12 & 0.07 & 451 & 0.91 & 0.03 & 6 \\
\hline Dorado & 3125 & $2580-35$ & 2.02 & 0.43 & 3.08 & 3.51 & 0.50 & 152 & 25 & 0.21 & 0.12 & 456 & 1.12 & 0.07 & 6 \\
\hline Dorado & 3135 & $2580-36$ & 1.89 & 2.44 & 3.31 & 5.75 & 0.56 & 175 & 30 & 1.29 & 0.42 & 412 & 0.95 & 0.05 & 5 \\
\hline Dorado & 3142.5 & $2580-43$ & 1.04 & 6.05 & 3.95 & 10.00 & 0.26 & 380 & 25 & 5.82 & 0.61 & 385 & 0.97 & 0.05 & 6 \\
\hline Dorado & 3145 & $2580-37$ & 0.87 & 0.29 & 0.67 & 0.96 & 0.51 & 77 & 59 & 0.33 & 0.30 & 450 & 1.07 & 0.06 & 5 \\
\hline Dorado & 3150 & $2580-38$ & 1.45 & 0.49 & 1.99 & 2.48 & 0.45 & 137 & 31 & 0.34 & 0.20 & 447 & 1.14 & 0.03 & 3 \\
\hline Average (total) & & & 1.34 & 1.26 & 2.69 & 3.95 & 0.71 & 203 & 55 & 0.97 & 0.27 & 420 & 0.70 & 0.04 & 5 \\
\hline Average (Paleogene) & & & 1.19 & 0.93 & 2.95 & 3.88 & 0.70 & 250 & 60 & 0.76 & 0.23 & 419 & 0.40 & 0.03 & 7 \\
\hline Average (Cretaceous) & & & 1.39 & 1.38 & 2.60 & 3.97 & 0.72 & 186 & 54 & 1.04 & 0.29 & 421 & 0.82 & 0.05 & 5 \\
\hline Barracuda & 2370 & $2615-8$ & 0.56 & 0.10 & 1.10 & 1.20 & 0.45 & 196 & 80 & 0.18 & 0.09 & 422 & & & \\
\hline Barracuda & 2430 & $2615-10$ & 0.74 & 0.12 & 1.41 & 1.53 & 0.88 & 191 & 119 & 0.16 & 0.08 & 420 & & & \\
\hline Barracuda & 2580 & $2615-15$ & 0.61 & 0.20 & 0.71 & 0.91 & 0.67 & 116 & 110 & 0.33 & 0.22 & 411 & & & \\
\hline
\end{tabular}


Table 1 (continued)

\begin{tabular}{|c|c|c|c|c|c|c|c|c|c|c|c|c|c|c|c|}
\hline \multirow[t]{2}{*}{ Exploration well } & \multirow[t]{2}{*}{ Depth (m) } & \multirow[t]{2}{*}{ Reference no. } & \multirow[t]{2}{*}{ TOC $(\%)$} & \multicolumn{9}{|c|}{ Rock-Eval pyrolysis } & \multicolumn{3}{|c|}{ Vitrinite reflectance } \\
\hline & & & & $S_{1}$ & $S_{2}$ & $S_{1}+S_{2}$ & $S_{3}$ & $\mathrm{HI}$ & OI & MI & PI & Tmax & Ro $(\%)$ & $\mathrm{SD}$ & Counts \\
\hline Barracuda & 2605 & $2615-16$ & 0.80 & 0.12 & 1.01 & 1.13 & 0.77 & 126 & 96 & 0.15 & 0.11 & 421 & & & \\
\hline Barracuda & 2690 & $2615-19$ & 1.01 & 0.11 & 2.11 & 2.22 & 0.56 & 209 & 55 & 0.11 & 0.05 & 427 & & & \\
\hline Barracuda & 2715 & $2615-20$ & 0.78 & 0.20 & 1.98 & 2.18 & 1.01 & 254 & 129 & 0.26 & 0.09 & 424 & & & \\
\hline Barracuda & 2745 & $2615-21$ & 0.70 & 0.22 & 2.34 & 2.56 & 0.70 & 334 & 100 & 0.31 & 0.09 & 403 & & & \\
\hline Barracuda & 2780 & $2615-22$ & 0.56 & 0.11 & 0.98 & 1.09 & 0.61 & 175 & 109 & 0.20 & 0.10 & 419 & & & \\
\hline Barracuda & 2820 & $2615-23$ & 0.99 & 0.23 & 0.87 & 1.10 & 0.67 & 88 & 68 & 0.23 & 0.21 & 413 & & & \\
\hline Barracuda & 2925 & $2615-26$ & 0.65 & 0.10 & 0.78 & 0.88 & 0.71 & 120 & 109 & 0.15 & 0.11 & 420 & & & \\
\hline Barracuda & 3090 & $2615-32$ & 1.01 & 0.35 & 3.87 & 4.22 & 1.01 & 383 & 100 & 0.35 & 0.08 & 427 & 0.55 & 0.05 & 14 \\
\hline Barracuda & 3280 & $2615-38$ & 0.87 & 0.32 & 0.81 & 1.13 & 0.66 & 93 & 76 & 0.37 & 0.28 & 388 & & & \\
\hline Barracuda & 3315 & $2615-39$ & 1.10 & 0.21 & 3.44 & 3.65 & 1.00 & 313 & 91 & 0.19 & 0.06 & 420 & 0.65 & 0.05 & 15 \\
\hline Barracuda & 3340 & $2615-40$ & 0.89 & 0.30 & 2.09 & 2.39 & 0.67 & 235 & 75 & 0.34 & 0.13 & 427 & & & \\
\hline Barracuda & 3370 & $2615-41$ & 1.23 & 0.60 & 2.78 & 3.38 & 0.81 & 226 & 66 & 0.49 & 0.18 & 430 & 0.66 & 0.04 & 14 \\
\hline Barracuda & 3400 & $2615-42$ & 1.34 & 0.34 & 4.09 & 4.43 & 0.90 & 305 & 67 & 0.25 & 0.08 & 428 & & & \\
\hline Barracuda & 3435 & $2615-43$ & 1.03 & 0.56 & 3.44 & 4.00 & 0.34 & 334 & 33 & 0.54 & 0.14 & 431 & 0.68 & 0.04 & 7 \\
\hline Barracuda & 3830 & $2615-45$ & 0.77 & 0.12 & 0.80 & 0.92 & 0.79 & 104 & 103 & 0.16 & 0.13 & 430 & & & \\
\hline Barracuda & 3835 & $2615-46$ & 0.80 & 0.12 & 1.34 & 1.46 & 1.01 & 168 & 126 & 0.15 & 0.08 & 427 & & & \\
\hline Barracuda & 4306.5 & $2615-66$ & 0.61 & 0.08 & 0.66 & 0.74 & 0.81 & 108 & 133 & 0.13 & 0.11 & 436 & & & \\
\hline Barracuda & 4325 & $2615-49$ & 1.56 & 0.56 & 6.50 & 7.06 & 0.70 & 417 & 45 & 0.36 & 0.08 & 433 & 0.88 & 0.05 & 14 \\
\hline Barracuda & 4345 & $2615-50$ & 1.43 & 0.71 & 5.98 & 6.69 & 0.87 & 418 & 61 & 0.50 & 0.11 & 434 & 0.94 & 0.06 & 10 \\
\hline Barracuda & 4380 & $2615-51$ & 1.89 & 0.66 & 7.01 & 7.67 & 0.66 & 371 & 35 & 0.35 & 0.09 & 433 & 1.02 & 0.03 & 15 \\
\hline Barracuda & 4405 & $2615-52$ & 1.44 & 0.43 & 6.22 & 6.65 & 0.98 & 432 & 68 & 0.30 & 0.06 & 436 & 1.09 & 0.05 & 14 \\
\hline Barracuda & 4425 & $2615-53$ & 1.23 & 0.30 & 4.77 & 5.07 & 1.01 & 388 & 82 & 0.24 & 0.06 & 434 & 1.08 & 0.04 & 13 \\
\hline Barracuda & 4485 & $2615-56$ & 0.65 & 0.16 & 0.78 & 0.94 & 0.71 & 120 & 109 & 0.25 & 0.11 & 420 & & & \\
\hline Barracuda & 4640 & $2615-61$ & 1.80 & 0.98 & 6.77 & 7.75 & 0.85 & 376 & 47 & 0.54 & 0.13 & 423 & 1.11 & 0.05 & 11 \\
\hline Barracuda & 4660 & $2615-62$ & 2.04 & 1.20 & 9.01 & 10.21 & 1.22 & 442 & 60 & 0.59 & 0.12 & 428 & 1.27 & 0.03 & 13 \\
\hline Barracuda & 4685 & $2615-63$ & 1.56 & 0.34 & 4.89 & 5.23 & 0.83 & 313 & 53 & 0.22 & 0.07 & 434 & 1.26 & 0.05 & 6 \\
\hline Barracuda & 4705 & $2615-64$ & 2.10 & 0.34 & 5.44 & 5.78 & 0.90 & 259 & 43 & 0.16 & 0.06 & 433 & 1.49 & 0.03 & 7 \\
\hline Barracuda & 4725 & $2615-65$ & 1.33 & 0.78 & 6.21 & 6.99 & 1.12 & 467 & 84 & 0.59 & 0.11 & 437 & & & \\
\hline Average (total) & & & 1.10 & 0.35 & 3.23 & 3.59 & 0.80 & 261 & 82 & 0.29 & 0.11 & 425 & 0.98 & 0.04 & 12 \\
\hline Average (Paleogene) & & & 0.87 & 0.25 & 1.99 & 2.24 & 0.73 & 218 & 87 & 0.27 & 0.12 & 419 & 0.64 & 0.05 & 13 \\
\hline Average (Cretaceous) & & & 1.37 & 0.48 & 4.74 & 5.23 & 0.89 & 313 & 75 & 0.32 & 0.09 & 431 & 1.13 & 0.04 & 11 \\
\hline
\end{tabular}

Total hydrocarbon potential $=\left(S_{1}+S_{2}\right)$, hydrogen index $\left(\mathrm{HI}=S_{2} / \mathrm{TOC} \times 100, \mathrm{mg} \mathrm{HC} / \mathrm{g} \mathrm{TOC}\right)$, oxygen index $\left(\mathrm{OI}=S_{3} / \mathrm{TOC} \times 100, \mathrm{mg} \mathrm{HC} / \mathrm{g}\right.$ TOC), migration index (MI $\left.=S_{1} / \mathrm{TOC}\right)$, and production index $\left(\mathrm{PI}=S_{1} / S_{1}+S_{2}\right)$

\section{Thermal maturity and hydrocarbon generation potential}

The vitrinite reflectance and Tmax values of the Mannar Basin range from 0.26 to $1.49 \%$ and 332 to $456{ }^{\circ} \mathrm{C}$, respectively (Table 1). It suggests the existence of both immature and mature sediments. Tmax and Ro values normally increase with temperature (Sykes and Snowdon 2002). In this study, a cross-plot of Tmax to Ro can probably indicate oxidised pseudo-vitrinite particles (Fig. 9). Similarly, graphite was also identified as pseudo-vitrinite particles (Ro > 3.54\%) in the Mannar Basin. These pseudo-vitrinite particles experienced higher thermal activities before erosion and deposition into a new geological cycle (Ratnayake and Sampei 2015b). In general, Tmax values are high in the Late Cretaceous sediments of the Mannar Basin (Fig. 9), as a result of increasing age and burial depth of sediments.

The value of ca. 0.55 Ro\% is normally recognised as a beginning level of oil generation window (Tissot and Welte 1978; Ryu 2008). Consequently, most of the analysed samples (except the Paleogene sediments in the Dorado well) have achieved oil to wet gas windows (Fig. 9). In addition, Ro (range from 0.26 to $0.52 \%$ ) and Tmax (range from 412 to $426^{\circ} \mathrm{C}$ ) values of the analysed Paleogene sediments in the Dorado well are plotted in the immature zone (Table 1). Similarly, Tmax values (range from 388 to $431{ }^{\circ} \mathrm{C}$ ) are lower in the Paleogene sediments of the Barracuda well (Table 1). Therefore, these younger and relatively shallow burial 
Barracuda

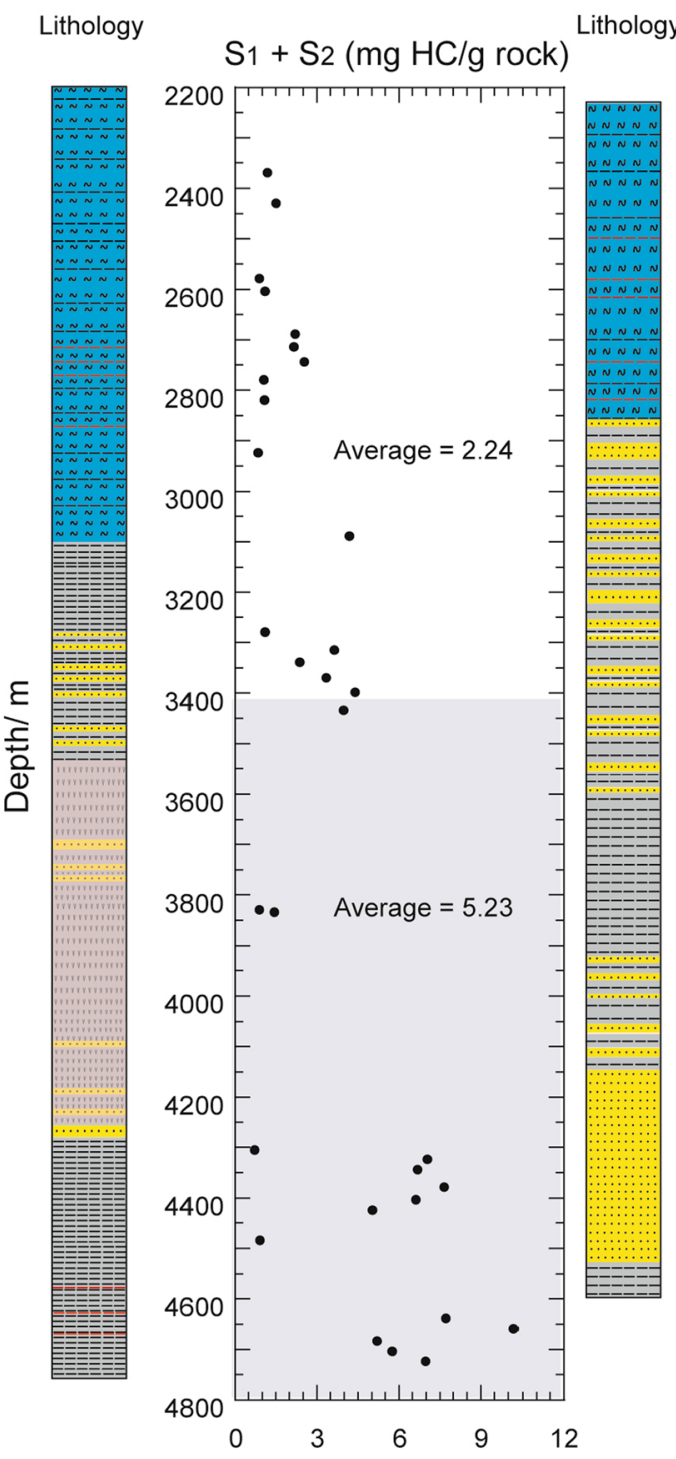

Dorado North

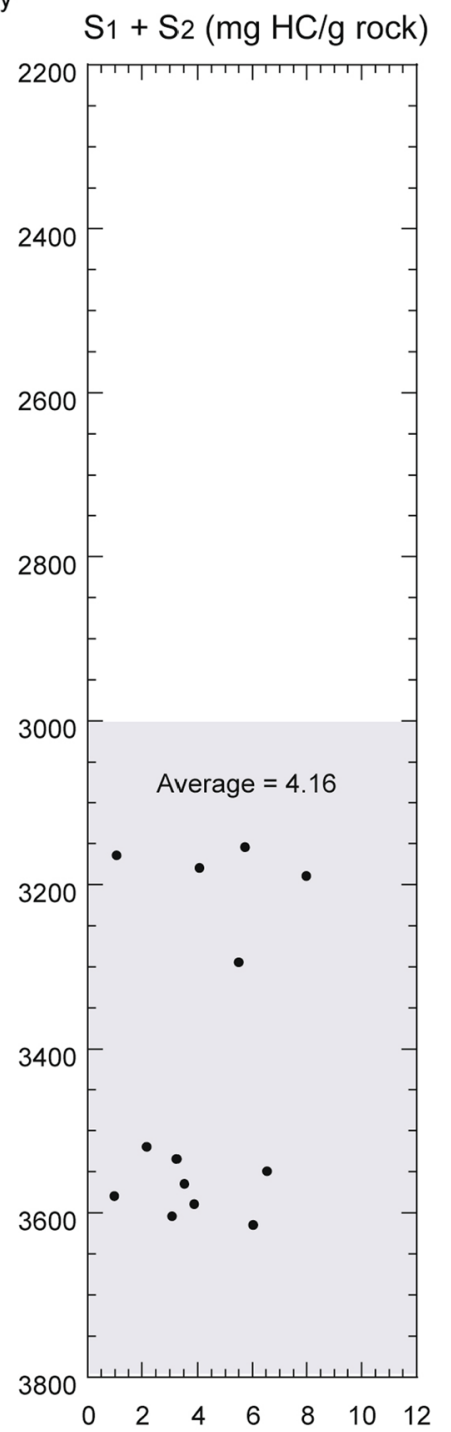

Dorado

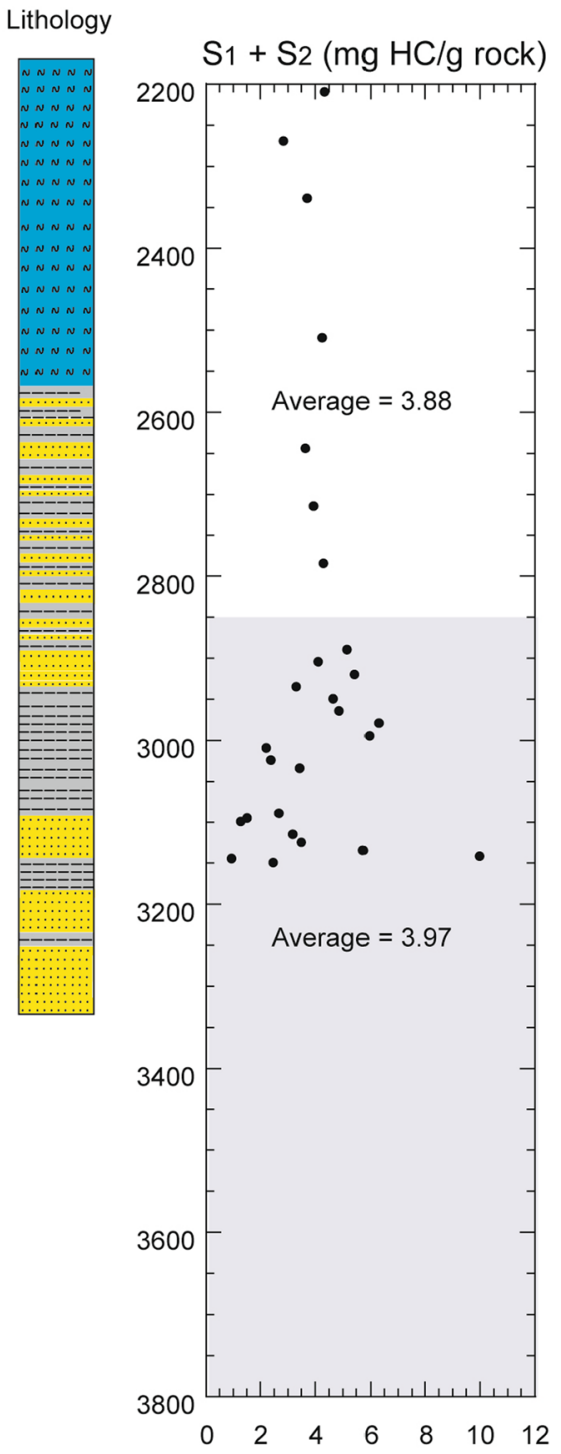

Fig. 3 Vertical variation in total hydrocarbon potential in the analysed samples. Lower grey parts show the Cretaceous sediments

Cenozoic sedimentary sequences can be regarded as immature to early mature for hydrocarbon generation. In addition, maturity of non-coaly sedimentary organic matter can also be expressed by the production index (PI) that is partially related to hydrocarbon expulsion (Fig. 10). PI values range from 0.03 to 0.61 (Table 1). It shows both early mature to mature sediments, as the value of 0.05 indicates a boundary of immature and mature organic matter (Adegoke et al. 2015; Du et al. 2015).

Similarly, HI versus Ro (\%) and Tmax plots can be widely used to determine types of generated hydrocarbon (i.e. oil and gas or mixed) from sedimentary organic matter
(Fig. 11). Most of the samples are plotted as Type II and Type III kerogen, although very few immature sediment samples are plotted between Type I and Type II kerogen from possibly contaminated cuttings (Fig. 11b). According to geochemical characteristics of cutting samples, the thermal maturity zone of the Mannar Basin is mainly associated with liquid hydrocarbons from the Late Cretaceous sediments of the Dorado and Barracuda wells. It suggests that thermal transformation is not sufficient to generate gas from available oil-gas prone (Type II-III) and gas prone (Type III) kerogen (Fig. 11b). In summary, the Late Cretaceous sediments are generally characterised by relatively 


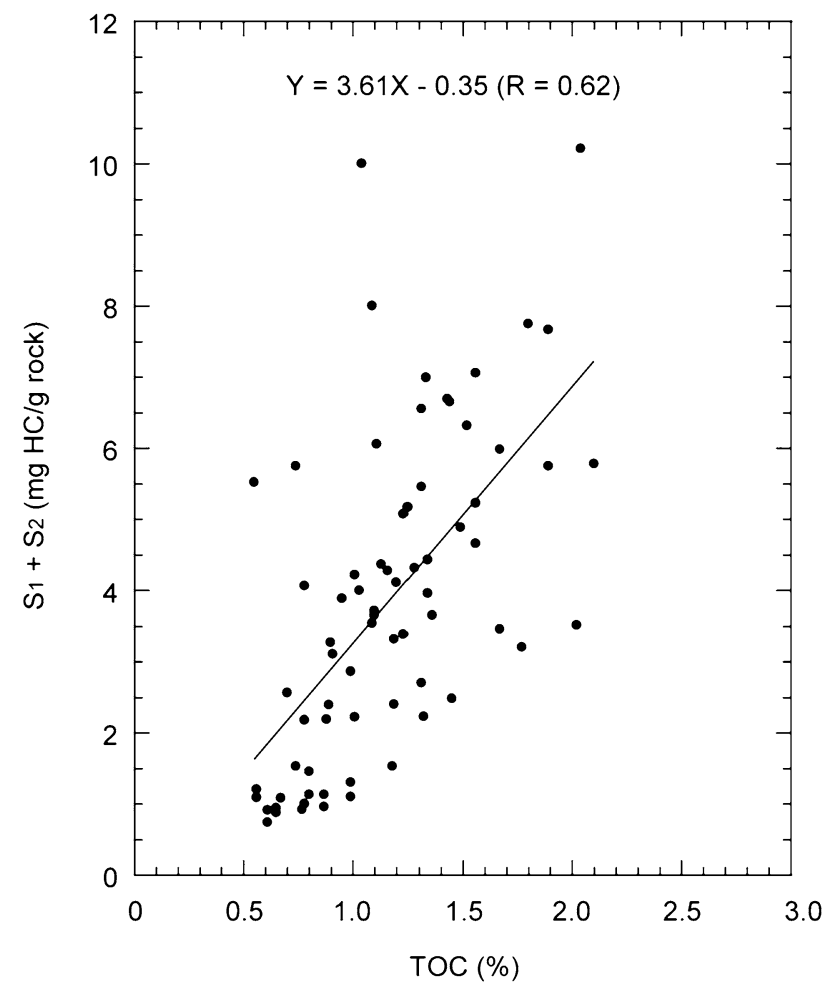

Fig. 4 Relationship between total hydrocarbon potential $\left(S_{1}+S_{2}\right)$ and total organic carbon [TOC (\%)]

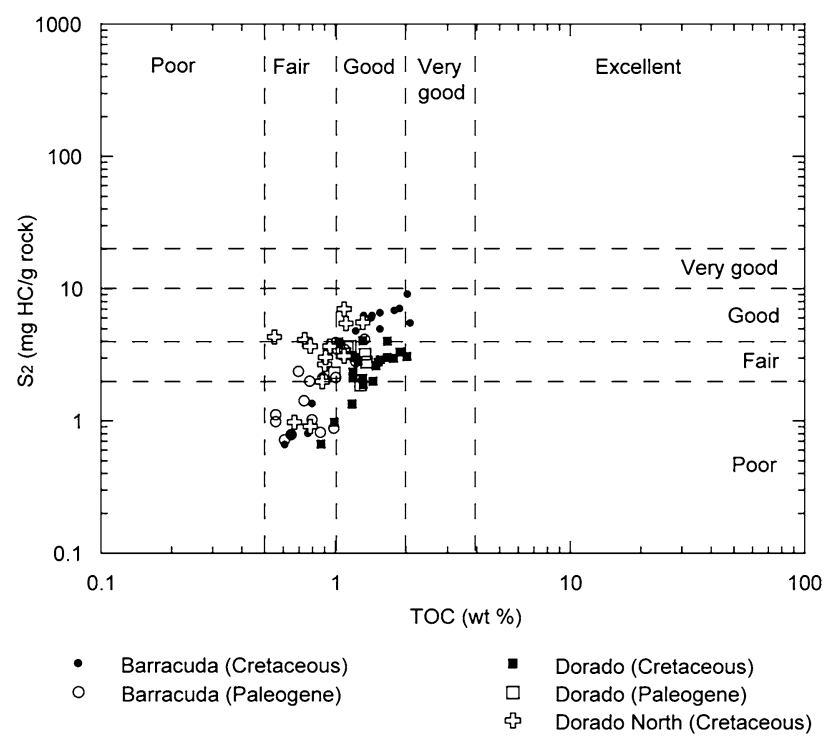

Fig. 5 Plot of $S_{2}$ versus TOC (\%) for determining organic richness of potential source rock beds

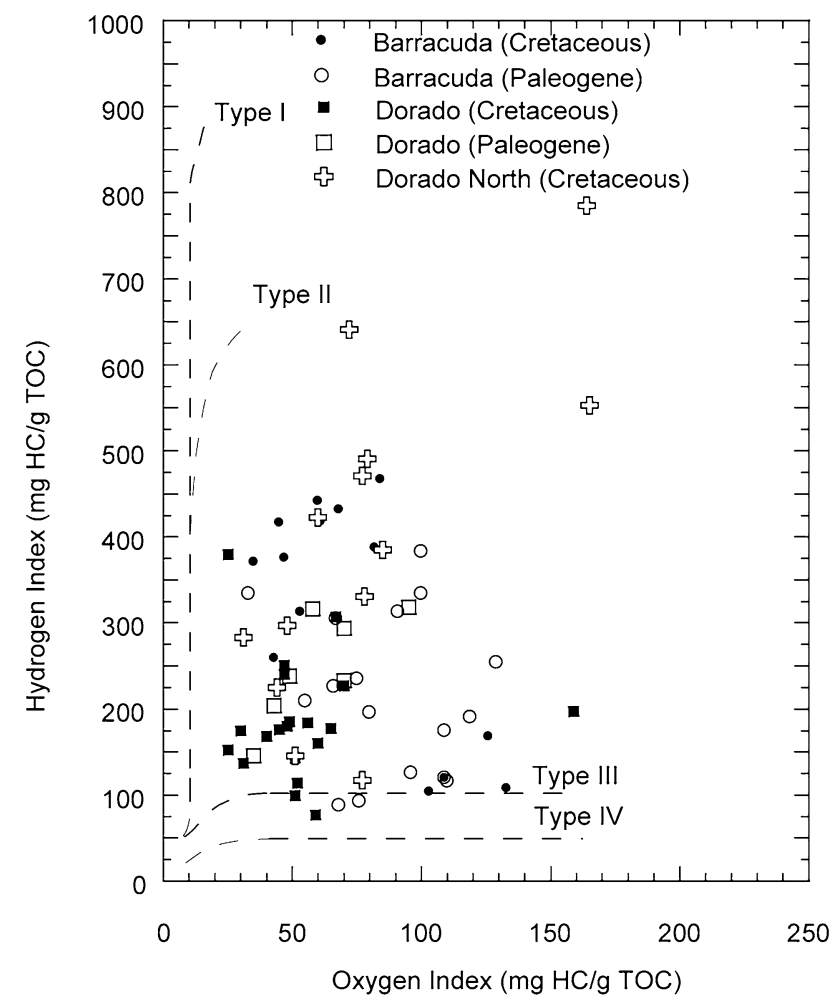

Fig. 6 Modified van Krevelen diagram based on hydrogen index (HI) versus oxygen index $(\mathrm{OI})$, showing kerogen type

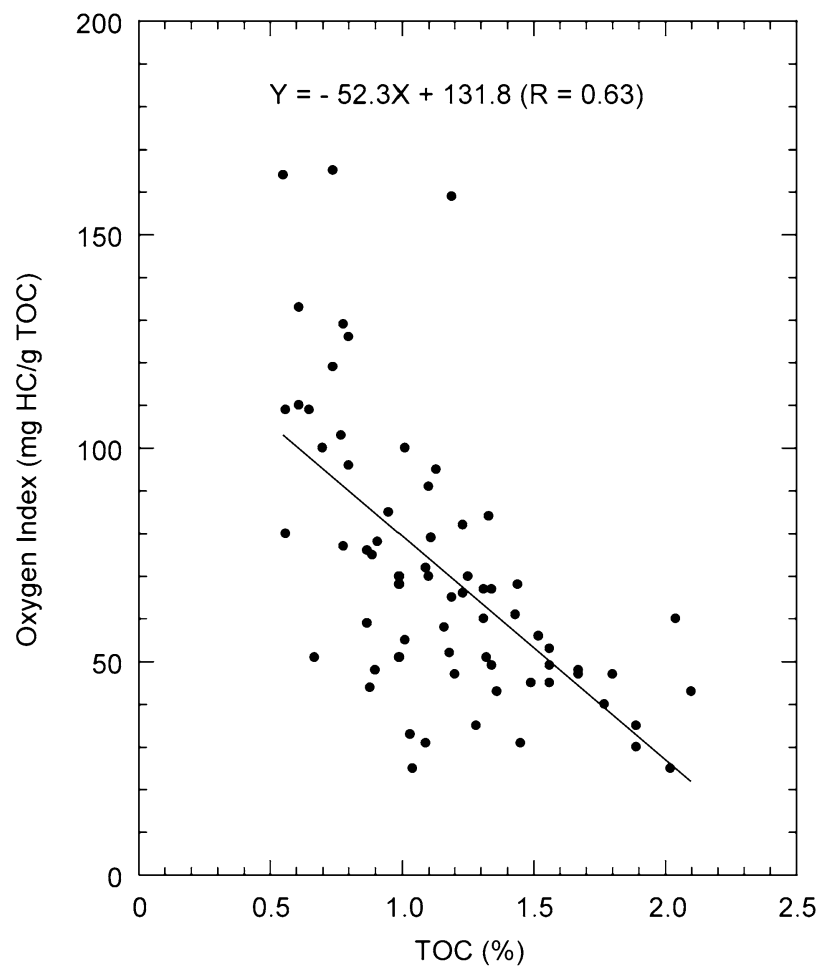

Fig. 7 Relationship between oxygen index (OI) and TOC (\%) in offshore sediments of the Mannar Basin 


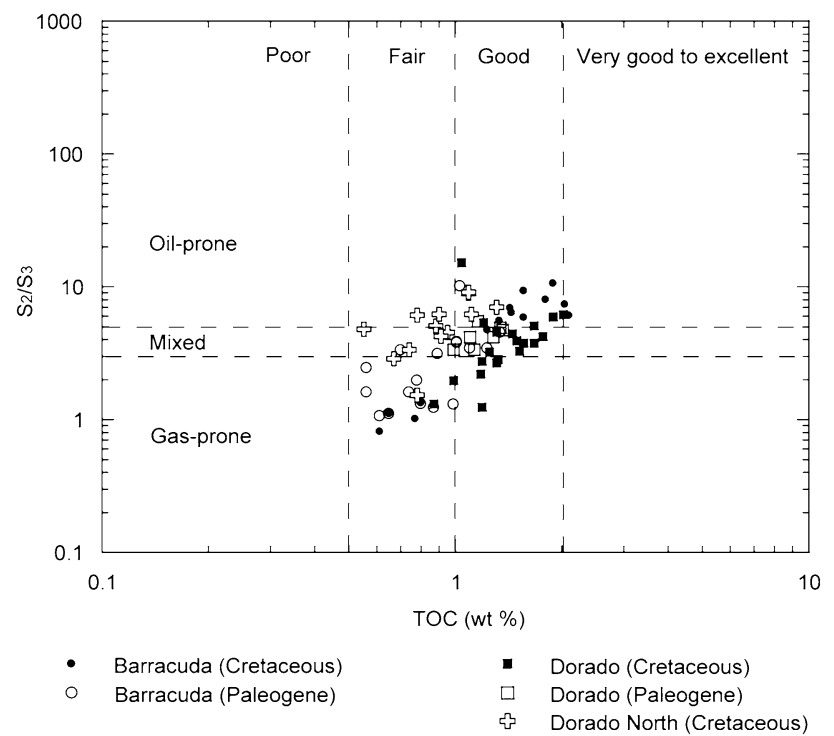

Fig. 8 Plot of $S_{2} / S_{3}$ versus TOC (\%) indicates the potential of hydrocarbon generation and type

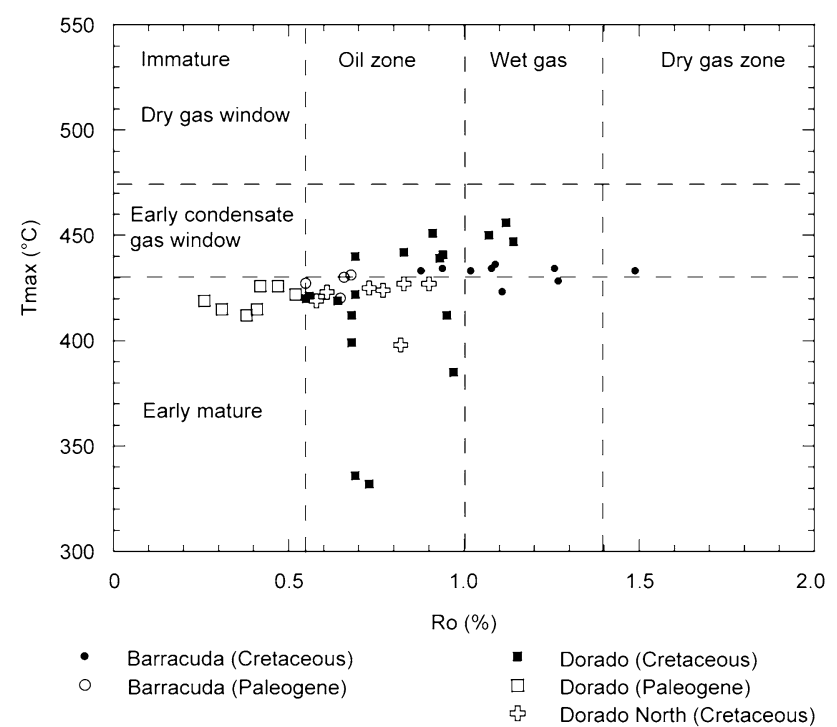

Fig. 9 Cross-plot of Rock-Eval Tmax and vitrinite reflectance (Ro) data of the Mannar Basin

high potential for oil generation (Fig. 11b). However, the Paleogene sediments are characterised by low potential for hydrocarbon generation (Fig. 11b).

Geochemical data can also be assessed to reconstruct geothermal history with respect to the geological evolution of the particular basin. Rifting basins are usually distinguished by a relatively high thermal capacity due to lithospheric

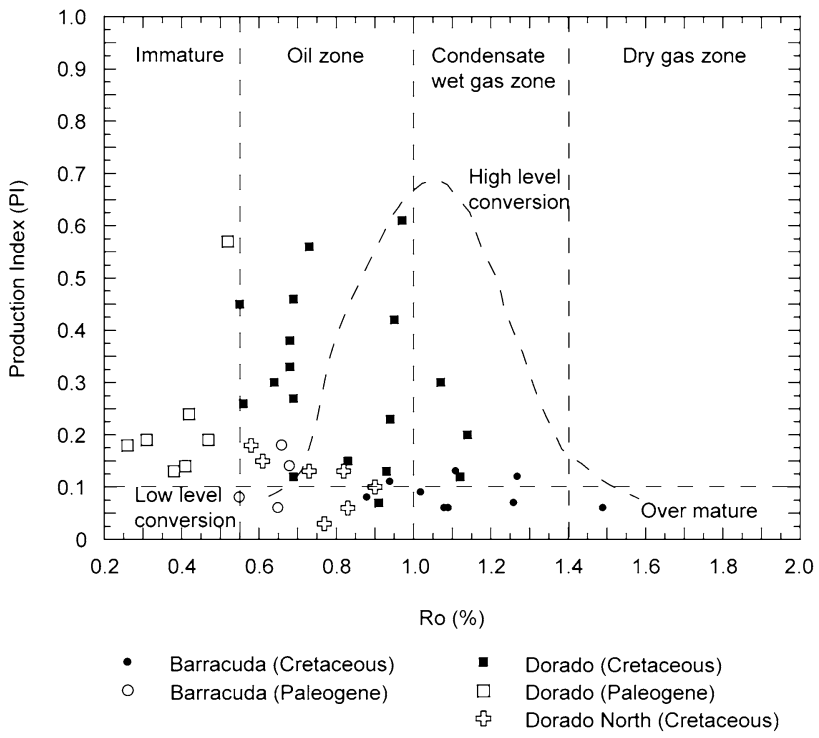

Fig. 10 Plot of Production Index (PI) versus vitrinite reflectance (Ro) data of the Mannar Basin

thinning (McKenzie 1978; Abbassi et al. 2014). The heat flow variations in rifting basins depend on nature and thickness of the lithosphere as a function of the geodynamic evolution of the particular basin. The Mannar Basin and surrounding oceanic basins record extensive igneous layers during the Late Cretaceous under the influence of rifting processes (e.g. Gombos et al. 1995; Galushkin 2015; Varma et al. 2015; Premarathne et al. 2016). However, the increment of Tmax values falls within a narrow range during the Cretaceous (Fig. 9). It suggests slightly higher palaeogeothermal gradient in the northeast margin of the basin during the Late Cretaceous. Therefore, the heat flow amplitude may partially support to generate gasses from the drilled Late Cretaceous sediments (Fig. 11).

\section{Basin modelling}

The kinetic model describes the timing of petroleum generation and expulsion via thermal conversion of kerogen in the Late Cretaceous sediments based on Rock-Eval pyrolysis data (Fig. 12). For example, transformation ratio and cumulative hydrocarbon generation depend on kerogen types (e.g. HI values) and maturity (Tmax). Simulating results show that the Dorado North, Dorado and Barracuda wells predominantly started the in situ oil and gas generation windows at ca. 40, 20 and $60 \mathrm{Ma}$, respectively (Fig. 12). The Barracuda well acquired peak generation during the Neogene Period 

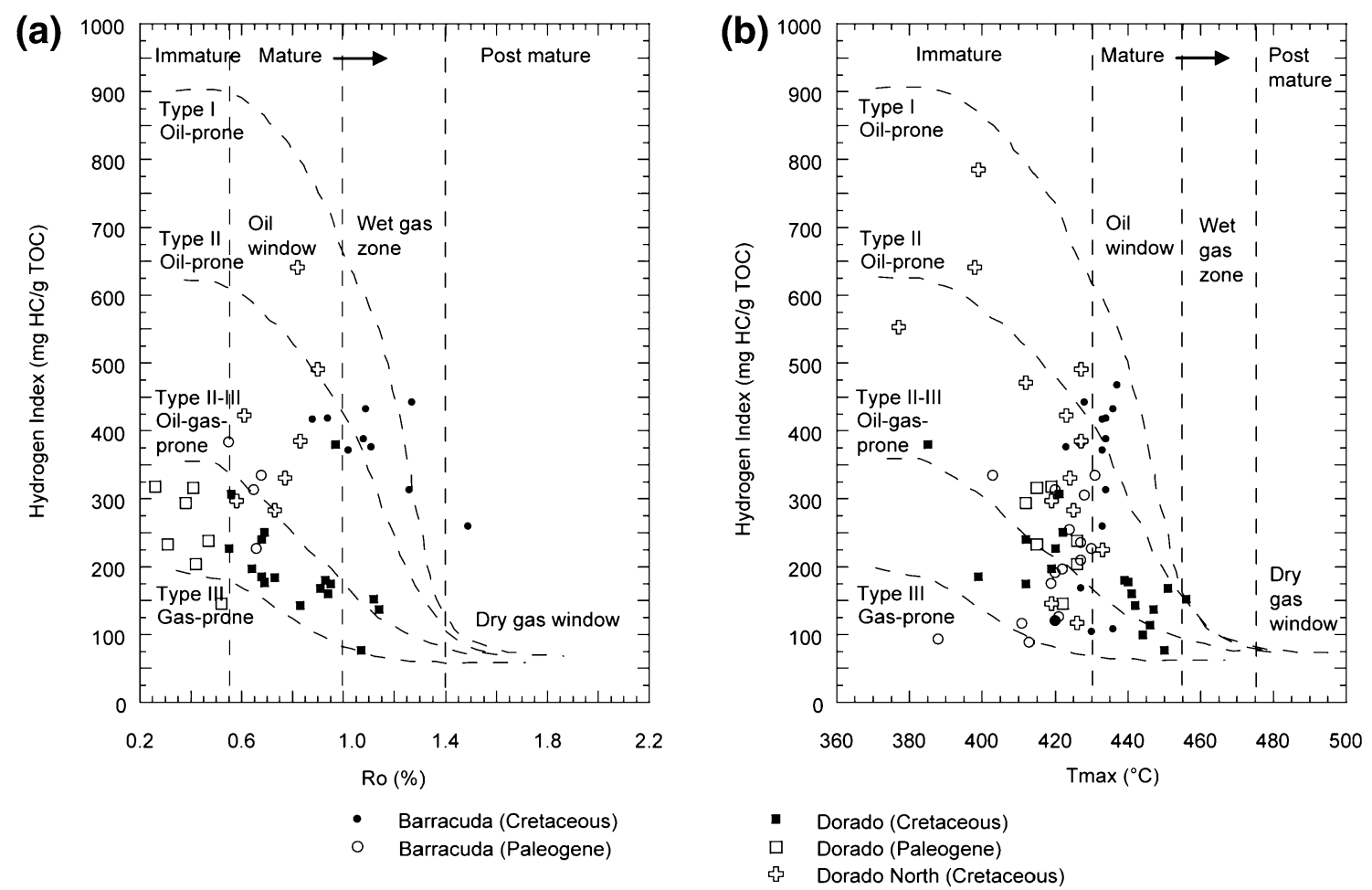

Fig. 11 Distribution of HI versus a vitrinite reflectance (Ro) and b Rock-Eval Tmax showing kerogen type and maturity of potential source rock beds in the Mannar Basin

(ca. 20 Ma, Fig. 12c). The in situ oil and gas generation rates of the Barracuda well are about $120 \mathrm{mg} / \mathrm{g}$ TOC and $190 \mathrm{mg} / \mathrm{g}$ TOC, respectively (Fig. 12c). Thus, it suggests nearly 1:1.6 oil to gas generation ratio. However, the Dorado North and Dorado wells have not yet reached to its peak generation for analysed samples (Fig. 12a, b), may be due to structural complexity of terrestrial kerogen. In general, cellulose- and lignin-rich terrestrial kerogen enhances hydrocarbon generative temperature of sedimentary organic matter (e.g. Tissot et al. 1987; Pepper and Corvi 1995; Hakimi et al. 2010). Finally, geochemical maturity proxies and model results indicate that the most likely higher matured rocks for gas expulsion can be probably located below the drilled depths of the exploration wells. However, these predicted models strongly depend on reconstructed paleo-heat flow properties.

\section{Conclusion}

Organic richness is higher in the Cretaceous calcareous mudstones than in the Paleogene calcareous silty/sandy mudstones in the Mannar Basin. TOC contents have a good correlation with total hydrocarbon potential in analysed sediments. TOC showed a negative correlation with OI, indicating that oxic marine bottom condition controlled TOC contents in this basin. Mixed Type II-III and Type III kerogen were predominantly recorded in the Late Cretaceous to Paleogene offshore sediments. Consequently, studied stratigraphic units in the Mannar Basin are more capable of generating gaseous than liquid hydrocarbons.

Tmax values are generally consistent with vitrinite reflectance data excluding possible pseudo-vitrinite particles. Tmax values show that the Late Cretaceous sediments of the Dorado (average $=421 \pm 35^{\circ} \mathrm{C}$ ) and Barracuda (average $=431 \pm 5^{\circ} \mathrm{C}$ ) wells have reached to mature stage for oil window. Therefore, it indicates incomplete thermal conversion of oil-gas prone (Type II-III) and gas prone (Type III) kerogen to wet gas zone. 1-D thermal modelling shows that onset of hydrocarbon generation started in the Early Paleogene for the Late Cretaceous sediments of the deeper Barracuda well. It reached the maximum in situ oil and gas generation at about $20 \mathrm{Ma}$. The amount of cumulative hydrocarbon generation can strongly depend on compositions and concentrations of Type II-III and Type III kerogen. 


\section{(a) Dorado North}

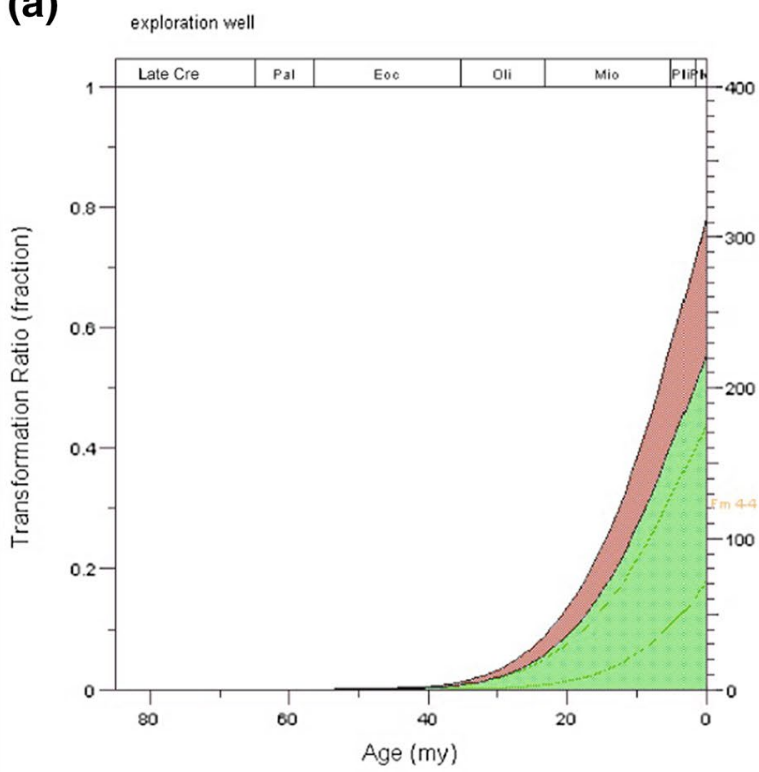

\section{(b) Dorado}

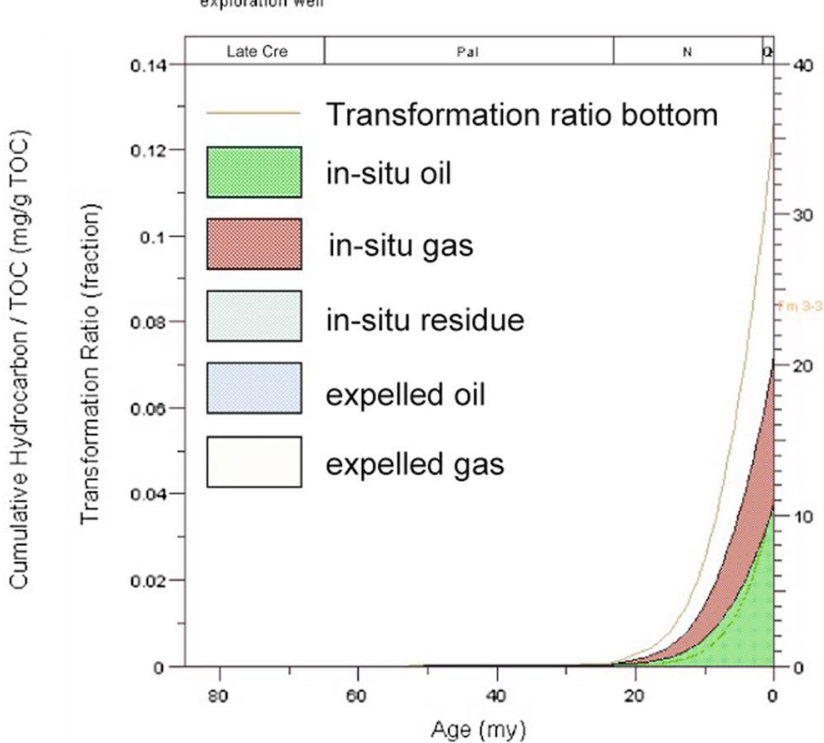

\section{Barracuda}

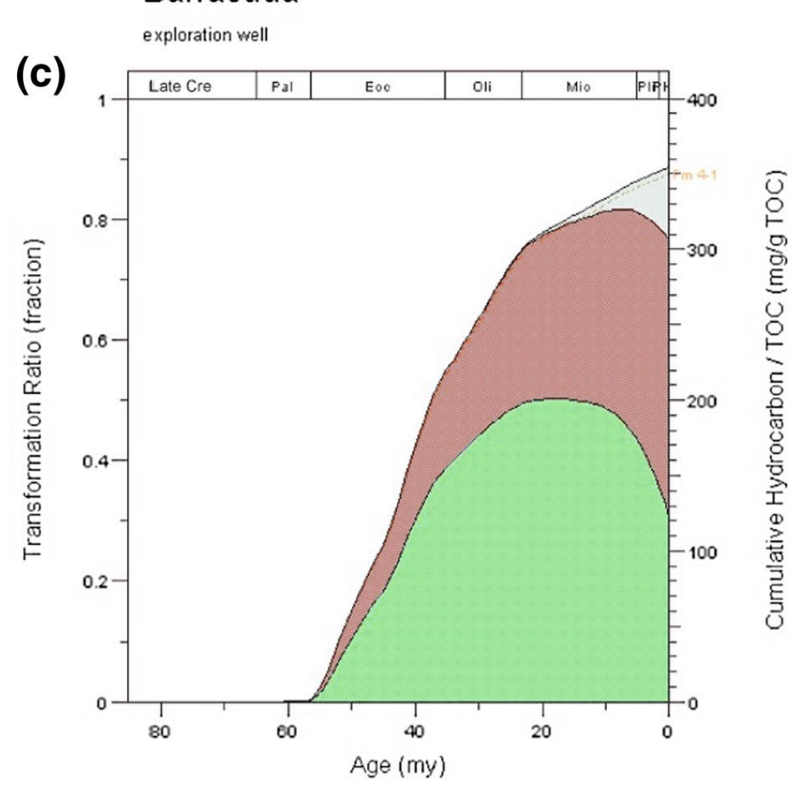

Fig. 12 Simplified compositional kinetic models based on standard rifting heat flows for a Dorado North, b Dorado, and $\mathbf{c}$ Barracuda exploration wells in the Mannar Basin

Acknowledgements The authors wish to greatly acknowledge the Director General Saliya Wickramasuriya of Petroleum Resources Development Secretariat (PRDS), Sri Lanka, for supplying the cuttings samples and necessary permission to publish this article.

Open Access This article is distributed under the terms of the Creative Commons Attribution 4.0 International License (http://creativecommons.org/licenses/by/4.0/), which permits unrestricted use, distribution, and reproduction in any medium, provided you give appropriate credit to the original author(s) and the source, provide a link to the Creative Commons license, and indicate if changes were made.

\section{References}

Abbassi S, George SC, Edwards DS, Primio RD, Horsfield B, Volk H (2014) Generation characteristics of Mesozoic syn- and post-rift source rocks, Bonaparte Basin, Australia: new insights from compositional kinetic modelling. Mar Pet Geol 50:148-165

Adegoke AK, Abdullah WH, Hakimi MH (2015) Geochemical and petrographic characterization of organic matter from the Upper Cretaceous Fika shale succession in the Chad (Bornu) Basin, northeastern Nigeria: origin and hydrocarbon generation potential. Mar Pet Geol 61:95-110 
Arab M, Bracène R, Roure F, Zazoun RS, Mahdjoub Y, Badji R (2015) Source rocks and related petroleum systems of the Chelif Basin, (western Tellian domain, north Algeria). Mar Pet Geol 64:363-385

Chandra K, Philip PC, Sridharan P, Chopra VS, Rao B, Saha PK (1991) Petroleum source-rock potentials of the Cretaceous transgressiveregressive sedimentary sequences of the Cauvery Basin. J Southeast Asian Earth 5:367-371

Chatterjee S, Goswami A, Scotese CR (2013) The longest voyage: tectonic, magmatic, and paleoclimatic evolution of the Indian plate during its northward flight from Gondwana to Asia. Gondwana Res 23:238-267

Cooray PG (1984) An introduction to the Geology of Sri Lanka, 2nd edn. Ceylon National Museum Publication, Colombo, pp 135-169

Delvaux D, Martin H, Leplat P, Paulet J (1990) Comparative RockEval pyrolysis as an improved tool for sedimentary organic matter analysis. Org Geochem 16:1221-1229

Du X, Song X, Zhang M, Lu Y, Lu Y, Chen P, Liu Z, Yang S (2015) Shale gas potential of the Lower Permian Gufeng Formation in the western area of the Lower Yangtze Platform, China. Mar Pet Geol 67:526-543

Espitalié J, Laporte JL, Madec M, Marquis F, Leplat P, Paulet J, Boutefeu A (1977) The rapid method for characterization of source rock origin; their petroleum potential and degree of evolution basic chemical element. Rev Inst Fr Pet 32:23-42

Galushkin YI (2015) Evolution of temperature, maturation level and realization of hydrocarbon potential in subtrappean sedimentary complex of the Bombay offshore-Results of 1-D basin modelling. Mar Pet Geol 67:804-815

Gombos AM, Powell WG, Norton IO (1995) The tectonic evolution of western India and its impact on hydrocarbon occurrences: an overview. Sediment Geol 96:119-129

Hakimi MH, Abdullah WH, Shalaby MR (2010) Source rock characterization and oil generating potential of the Jurassic Madbi Formation, onshore East Shabowah oilfields, Republic of Yemen. Org Geochem 41:513-521

Ichron limited (2012) A biostratigraphical evaluation and petrographical, diagenetic and reservoir quality assessment of wells Dorado91H/1Z, Barracuda-1G/1, Dorado North-82 k/1, Block SL 200701-001, Mannar Basin. Sri Lanka, Cairn Lanka Pty Limited

Jiang H, Pang X, Shi H, Yu Q, Cao Z, Yu R, Chen D, Long Z, Jiang F (2015) Source rock characteristics and hydrocarbon expulsion potential of the Middle Eocene Wenchang formation in the Huizhou depression, Pearl River Mouth basin, south China Sea. Mar Pet Geol 67:635-652

Katz BJ (1983) Limitation of 'Rock-Eval' pyrolysis for typing organic matter. Org Geochem 4:195-199

Kularathna EKCW, Pitawala HMTGA, Senarathne A, Senevirathne BSMCK, Weerasinghe DA (2015) Forced-fold structures in the Mannar Basin, Sri Lanka: modes of occurrence, development mechanism and contribution for the petroleum system. J Geol Soc Sri Lanka 17:53-63

Langford FF, Blanc-Valleron MM (1990) Interpreting Rock-Eval pyrolysis data using graphs of pyrolizable hydrocarbon vs. total organic carbon. AAPG Bull 74:799-804

Mani D, Patil DJ, Dayal AM, Prasad BN (2015) Thermal maturity, source rock potential and kinetics of hydrocarbon generation in Permian shales from Damodar Valley basin, Eastern India. Mar Pet Geol 66:1056-1072

Mashhadi ZS, Rabbani AR, Kamali MR (2015) Geochemical characteristics and hydrocarbon generation modeling of the Kazhdumi (Early Cretaceous), Gurpi (Late Cretaceous) and Pabdeh (Paleogene) formations, Iranian sector of the Persian Gulf. Mar Pet Geol 66:978-997

McKenzie D (1978) Some remarks on the development of sedimentary basins. Earth Planet Sci Lett 40:25-32
McKenzie D, Sclater JG (1971) The evolution of the Indian Ocean since the Late Cretaceous. Geophys J R Astr Soc 25:437-528

Molnar P, Tapponnier P (1975) Cenozoic tectonics of Asia: effects of a continental collision. Science 189:419-426

Norton IO, Sclater JG (1979) A model for the evolution of the Indian Ocean and the breakup of Gondwanaland. J Geophys Res 84:6803-6830

Pepper AS, Corvi PJ (1995) Simple kinetic models of petroleum formation. Part I: oil and gas generation from kerogen. Mar Pet Geol 12:291-319

Pepper AS, Dodd TA (1995) Simple kinetic models of petroleum formation. Part II: oil-gas cracking. Mar Pet Geol 12:321-340

Peters KE (1986) Guidelines for evaluating petroleum source rock using programmed pyrolysis. AAPG Bull 70:318-329

Peters KE, Cassa MR (1994) Applied source rock geochemistry. In: Magoon LB, Dow WG (eds) The petroleum system from source to trap, AAPG Memoirs, vol 60, pp 93-120

Premarathne U, Suzuki N, Ratnayake N, Kularathne C (2016) Burial and thermal history modelling of the Mannar Basin, offshore Sri Lanka. J Pet Geol 39:193-214

Ratnayake AS (2016) Regionwide geodynamic analyses of the Cenozoic carbonate burial in Sri Lanka related to climate and atmospheric $\mathrm{CO}_{2}$. Int J Econ Environ Geol 7:1-9

Ratnayake AS, Sampei Y (2015a) Characterization of organic matter and depositional environment of the Jurassic small sedimentary basins exposed in the northwest onshore area of Sri Lanka. Res Org Geochem 31:15-28

Ratnayake AS, Sampei Y (2015b) Preliminary prediction of the geothermal activities in the frontier Mannar Basin, Sri Lanka. J Geol Soc Sri Lanka 17:19-29

Ratnayake AS, Sampei Y, Kularathne CW (2014) Stratigraphic responses to major depositional events from the Late Cretaceous to Miocene in the Mannar Basin, Sri Lanka. J Geol Soc Sri Lanka $16: 5-18$

Ratnayake AS, Sampei Y, Kularathne CW (2017a) Current status of hydrocarbon exploration in Sri Lanka. Int J Oil Gas Coal Technol 16:377-389

Ratnayake AS, Sampei Y, Ratnayake NP, Roser BP (2017b) Middle to late Holocene environmental changes in the depositional system of the tropical brackish Bolgoda Lake, coastal southwest Sri Lanka. Palaeogeogr Palaeoclimatol Palaeoecol 465:122-137

Ritter U (1984) The influence of time and temperature on vitrinite reflectance. Org Geochem 6:473-480

Ryu I (2008) Source rock characterization and petroleum systems of Eocene Tyee Basin, southern Oregon Coast Range, USA. Org Geochem 39:75-90

Shaw RD (2002) TGS-NOPEC SL01-phase one offshore Sri Lanka seismic survey interpretation report. New South Global Pty Ltd, pp 1-45

Storey M, Mahoney JJ, Saunders AD, Duncan RA, Kelley SP, Coffin MF (1995) Timing of hot spot-related volcanism and the breakup of Madagascar and India. Science 267:852-855

Sweeney JJ, Burnham AK (1990) Evaluation of a simple model of vitrinite reflectance based on chemical kinetics. AAPG Bull 74:1559-1570

Sykes R, Snowdon LR (2002) Guidelines for assessing the petroleum potential of coaly source rocks using Rock-Eval pyrolysis. Org Geochem 33:1441-1455

Tissot BP, Welte DH (1978) Petroleum formation and occurrences. Springer-Verlag, New York, pp 3-201

Tissot B, Demaison G, Masson P, Delteil JR, Combaz A (1980) Paleoenvironment and petroleum potential of Middle Cretaceous black shales in Atlantic Basins. AAPG Bull 64:2051-2063

Tissot BP, Pelet R, Ungerer P (1987) Thermal history of sedimentary basins, maturation indices, and kinetics of oil and gas generation. AAPG Bull 71:1445-1466

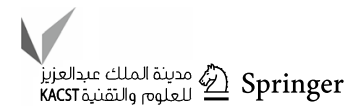


Uysal IT, Glikson M, Golding SD, Audsley F (2000) The thermal history of the Bowen Basin, Queensland, Australia. vitrinite reflectance and clay mineralogy of Late Permian coal measures. Tectonophysics 323:105-129

Vandenbroucke M, Largeau C (2007) Kerogen origin, evolution and structure. Org Geochem 38:719-833

Varma AK, Hazra B, Mendhe VA, Chinara I, Dayal AM (2015) Assessment of organic richness and hydrocarbon generation potential of Ranigani basin shales, West Bengal, India. Mar Pet Geol 59:480-490

Welte DH, Yukler MA (1981) Petroleum origin and accumulation in basin evolution-A quantitative model. AAPG Bull 65:1387-1396

Publisher's Note Springer Nature remains neutral with regard to jurisdictional claims in published maps and institutional affiliations. 